\title{
Thuma Mina: A critical discourse on the prospect of a Ramaphosa presidency through the lenses of Isaiah 6:8
}

\begin{tabular}{|c|c|}
\hline \multicolumn{2}{|c|}{$\begin{array}{l}\text { Authors: } \\
\text { Thinandavha D. Mashau } 1 \text { (1) } \\
\text { Mookgo S. Kgatle }{ }^{1} \text { (『) }\end{array}$} \\
\hline \multicolumn{2}{|c|}{$\begin{array}{l}\text { Affiliations: } \\
{ }^{1} \text { Department of Christian } \\
\text { Spirituality, Church History } \\
\text { and Missiology, School of } \\
\text { Humanities, College of } \\
\text { Human Sciences, University } \\
\text { of South Africa, Tshwane, } \\
\text { South Africa }\end{array}$} \\
\hline \multicolumn{2}{|c|}{$\begin{array}{l}\text { Corresponding author: } \\
\text { Mookgo Kgatle, } \\
\text { kgatls@unisa.ac.za }\end{array}$} \\
\hline \multicolumn{2}{|c|}{$\begin{array}{l}\text { Dates: } \\
\text { Received: } 16 \text { July } 2020 \\
\text { Accepted: } 03 \text { Feb. } 2021 \\
\text { Published: } 30 \text { Apr. } 2021\end{array}$} \\
\hline \multicolumn{2}{|c|}{$\begin{array}{l}\text { How to cite this article: } \\
\text { Mashau, T.D. \& Kgatle M.S., } \\
\text { 2021, 'Thuma Mina: A critical } \\
\text { discourse on the prospect of } \\
\text { a Ramaphosa presidency } \\
\text { through the lenses of Isaiah } \\
\text { 6:8', Verbum et Ecclesia } 42(1) \text {, } \\
\text { a2129. https://doi.org/ } \\
\text { 10.4102/ve.v42i1.2129 }\end{array}$} \\
\hline \multicolumn{2}{|c|}{$\begin{array}{l}\text { Copyright: } \\
\text { ( ) 2021. The Authors } \\
\text { Licensee: AOSIS. This } \\
\text { is licensed under the } \\
\text { Creative Commons } \\
\text { Attribution License. }\end{array}$} \\
\hline \multicolumn{2}{|l|}{ Read online: } \\
\hline 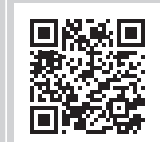 & $\begin{array}{l}\text { Scan this QR } \\
\text { code with your } \\
\text { smart phone or } \\
\text { mobile device } \\
\text { to read online. }\end{array}$ \\
\hline
\end{tabular}

This article explores the prospect of the Ramaphosa presidency and its success by reflecting on the 'Thuma Mina' concept. In his State of the Nations Address on 16 February 2018, President Ramaphosa cited the Thuma Mina song of Hugh Masekela to mobilise the resourcefulness of South Africans to volunteer their services to create a better future for all. In this article, it becomes clear that 'Thuma Mina' is more than just a song by Hugh Masekela and churches; it has deep roots in Isaiah 6:8 and the narrative of Isaiah's calling by God to be a prophet. In embracing the 'Thuma Mina' concept, Ramaphosa's presidency has a prospect of succeeding against all odds. The president must just remain rooted to its historical significance, its connectivity to Yahweh (YHWH) and the good will of the people of South Africa as engraved in Ubuntu and the spirit of volunteerism, servanthood and generosity.

Interdisciplinary and/or interdisciplinary implications: This article brings the disciplines of theology, leadership and politics in defining 'Thuma Mina' and the prospect of the Ramaphosa presidency. It proposes that the continued use of 'Thuma Mina' will remain a driver to mobilise South Africans to embrace the spirit of volunteerism, servanthood and sacrifice to bring about lasting solutions to challenges of decay that South Africa faces.

Keywords: Thuma Mina; critical discourse; Cyril Ramaphosa; presidency; leadership; Isaiah 6:8.

\section{Introduction}

Since the election of Matamela Cyril Ramaphosa as a president of the African National Congress (ANC) in December 2017, during their 54th elective conference in Nasrec, and his appointment as the president of the country in 2018, there has been a sign of hope and a better future for all South Africans. Speaking in the context of President Cyril Ramaphosa's State of the Nation Address 2 days after the resignation of Jacob Zuma, Maluleke (2018) captures the kind of hope as follows:

The speech contained several titillating ideas but it was Ramaphosa's quotation of the words of Hugh Masekela's song, Thuma Mina/Send Me at the end of his speech [State of the Nation Address] that appears to have been particularly inspirational. So much so that - as he told Parliament in his reply to the debate on his speech - many South Africans sent him messages consisting of only two words: 'Send Me'. (p. 1)

'Thuma Mina' is a phrase which is common amongst the isiZulu, isiXhosa and isiNdebele' speaking people of South Africa - it means 'Send me' (Göranzon 2019:175). This concept has been used as a title of a song by Hugh Masekela as quoted by President Ramaphosa and already noted above. However, it is a popular chorus sung in South African churches (Göranzon 2019:175) and has as its roots in Isaiah 6:8 (Maluleke 2018). Even though Maluleke's views, with regard to the origin of the song 'Thuma Mina', first appeared in the 'Daily Maverick', it has since then received positive review and reception amongst scholars who seem to agree with him (Barnard-Naudé 2020:222; Beckmann 2019:2). Tapping into the religious commitment of Ramaphosa, Beckmann (2019) concluded as follows:

Although one cannot aver that the President definitely wanted to invoke the specific verse from the Old Testament when he made the call, it is very likely that he knew the origin of the phrase, Thuma mina, given his own religious upbringing and leadership of Christian youth movements. (pp. 2-3)

Writing in the context of Cyril Ramaphosa's 2018 Thuma Mina moments, Odwa (2018) concluded that his adopted phrase 'Thuma Mina' has become Ramaphosa's manifesto which has now become more synonymous to his name and the new dawn of his presidency. However, there are 
those whose excitement and hope start to diminish by the end of the day. In writing about, 'the destruction of Thuma Mina', the editorial of Mail \& Guardian (2019) concluded that:

Thuma Mina is now a joke phrase, used as shorthand in conversations to indicate a shared understanding of just how much trouble we are in. Joking is how we survive. It's how we come to grips with an economy, broken by Eskom, teetering on the edge of a junk status grading. The darkness is here. (p. 1)

Irrespective of negative comments like this one, a glimpse of hope remains in this country. The rapid response by President Ramaphosa and the manner in which he is leading the country against the invisible enemy of coronavirus disease 2019 (COVID-19) are one such example of hope in the prospect of his presidency. The manner in which private sectors, politicians, churches, faith-based organisations and ordinary citizens responded to the president's call for the 'Thuma Mina' Solidarity Fund shows how Ramaphosa can still on the ubuntu philosophy of life amongst South Africans propel the 'Thuma Mina' drive. The main research question that this article seeks to answer therefore is: How can Ramaphosa's use of Thuma Mina, drawing from Isaiah 6:8, inspire hope and a prospect of success to his presidency? To achieve this, the first section of this article will deal with Ramaphosa, his rise to presidency and use of the "Thuma Mina' concept. This will be followed by a section on the use of 'Thuma Mina' as a theological concept in Isaiah 6:8. The article will then be concluded by reflecting on the prospect of Ramaphosa's presidency by drawing some parallelism with the 'Thuma Mina' in Isaiah 6:8.

\section{Ramaphosa, his leadership style and use of the 'Thuma Mina' concept}

\section{Ramaphosa: A very short biography}

Ramaphosa was born in Soweto, west of Johannesburg, on 17 November 1952 (Butler 2011:1). According to South African History Online (2018), he got his school-leaving certificate (matriculation) at Mphaphuli High School, Sibasa, Venda, in 1971, after which he enrolled to study for a law degree at the then University of the North (now University of Limpopo) in 1972. It was at this university that Ramaphosa became actively involved in politics, joining student formations like the South African Student Organisation (SASO) and the Black People's Convention (BPC). Unfortunately, Ramaphosa could not complete his studies at the University of the North because of his student activism and had to rather look for a job. It was during his employment with a law firm in Johannesburg that Ramaphosa enrolled with the University of South Africa and completed his B Proc degree in 1981 (Nkambule 2014). He was then employed as a legal advisor to the Council of Unions of South Africa (CUSA). The CUSA asked Ramaphosa to start the National Union of Mineworkers (NUM) and was the founding general secretary. Ramaphosa became the chairperson of what is known as the 'reception committee' in the ANC, where he was responsible for receiving Rivonia trialists (DPME 2018). He was elected secretary general of the ANC in 1991 after the unbanning of the party (City Press 2017). He was also head of the team of negotiations for the ANC at the Convention for a Democratic South Africa (DPME 2018).

In 1994 with the dispensation of democracy, Ramaphosa was elected member of the parliament and chairperson of the constitutional assembly (News24 2017). It was during this time that he became an overseer for drafting the first democratic constitution in South Africa (Ramaphosa 2017). After his short stay in parliament, Ramaphosa left and resigned as secretary of the ANC to become one of the top business people in South Africa (DPME 2018). According to Hartley (2017:130), Ramaphosa's comeback to politics happened in December 2012 when he was elected as the ANC deputy president during their elective conference in Mangaung. Following his election in the ANC, he then became the deputy president of South Africa in 2014 (DPME 2018).

There is no other way to explain his rise to the presidency of both the ANC and South Africa than to quote a song that his supporters were singing during the ANC elective conference on 18 December 2017 - Phakama Ramaphosa ixesha lefikile [Rise, Ramaphosa, your time has come]. Immediately after the announcement that Ramaphosa would be the new president of the ANC, the markets became very excited; they responded even more positively when Ramaphosa was officially sworn in as the new president of South Africa on 15 February 2018. The rise of Ramaphosa is called the new dawn. This concept promises a new beginning for South Africans. It is ironic that this concept echoes the name of the official residence of the South African president that is Mahlamba Ndlopfu, which is like the White House in the United States of America. Mahlamba Ndlopfu means 'new dawn', an indication that new things have come to the land and 'Thuma Mina' remains the driver of this new dawn; hence there is a need to unpack how Ramaphosa uses this concept to drive the success of his presidency.

\section{Ramaphosa's leadership style}

There could be many styles of leadership demonstrated by Ramaphosa over the years. We want to share five in this article.

Firstly, Ramaphosa is a negotiator. This skill is seen when Ramaphosa led the negotiating team for the ANC during CODESA and was able to negotiate with the National Party for the democratic elections in 1994 (Hartley 2017:2 cf. Burnard 2017:3). His negotiating skill is also seen when the former president Jacob Zuma appointed Ramaphosa in 2012 to become a mediator to solve various conflicts that existed in the factions in South Sudan (Burnard 2017:4). Ramaphosa also became a negotiator in Lesotho between different parties where they agreed to have elections. After his election as the president of the ANC in 2017, Ramaphosa had to negotiate an exit plan for Zuma. Many people criticised him for delaying Zuma's removal, but Ramaphosa negotiated 
until the very day that Zuma announced his resignation as the president of South Africa.

Secondly, Ramaphosa is a unifier. He was instrumental in not only bringing unity amongst the trade unions in South Africa in 1985 (Hartley 2017:28), but also in the tripartite alliance comprised of the ANC, the South African Communist Party (SACP) and the Confederation of South African Trade Unions (COSATU) (Cilliers 2017:1). In the previous administration, the same structures experienced divisions with each member of the tripartite alliance pulling in their own direction. As the new president, Ramaphosa is able to unite South Africans with his 'Thuma Mina' concept that we discuss below. Equally, the tensions that used to be rife in parliament during the previous administration is now neutralised under Ramaphosa. In addition, Ramaphosa is able to speak different languages of South Africa depending on where he is addressing the crowd. Thus, when in the Eastern Cape, he likes to address the crowd in Xhosa, Zulu when he is in Kwazulu Natal and Tsonga when he is in Limpopo (News24 2017).

Thirdly, Ramaphosa is an ethical leader. According to Hartley (2017:191), 'Ramaphosa has no association with any of the corruption scandals plaguing South Africa'. The Johannesburg Review of Books (2018) states that Ramaphosa does not appear in the list of politicians who were involved in the arms deal. In addition, Ramaphosa does not appear in the Gupta e-mails that reveal conversation of politicians involved in state capture and other corruption-related activities. Thus, he has been able to build trust between himself and the citizenry of South Africa as he has demonstrated some sense of integrity and dignity (Butler 2011). Butler (2011) continues to say that he has an ability to do both business and politics with high ethical standards. Furthermore, he has been insistent on good financial management in business, politics, unions, government and so forth (Ramaphosa 2017). He illustrated this when he declared all his interests and removed possible conflicts (Ramaphosa 2017).

Fourthly, Ramaphosa is a transformational leader. Transformational leadership is the ability to effect change in an organisation (Kgatle 2016:63). According to Butler (2011:351), he aimed at transforming a democratic business specifically in light of Black Economic Empowerment (BEE) to increase black ownership, black management and black control of South African business. Consequently, most black people who are now participant as BEE have adopted a 'broad based' policy that encourages the development of small and medium enterprises. Ramaphosa was instrumental in the development of this BEE policy together with the National Development Plan (NDP) and other transformative policies in the ANC-led government. In addition, according to DPME (2018), Ramaphosa used his personal businesses and foundation to promote black women leadership and supported students with financial needs in institutions of higher learning. His businesses also helped small blackowned business and schools in the townships and rural areas. Ramaphosa has proper vision to bring jobs into the economy in order to bring transformation of the economy. Thus, his vision is clear and with the support of the leadership collective of the ANC and the citizens of the country society can be transformed to its full potential (Ramaphosa 2017).

Fifthly, Ramaphosa is a humble leader. The better way to describe Ramaphosa is the phrase 'gentle giant'. Butler (2011:391) describes that Ramaphosa, who although meets with great and high-profile people like presidents and prime ministers, is also able to demonstrate signs of humility. As a humble leader, Ramaphosa is able to recognise the worth of others, including his own opponents and actually goes further to affirm their worthiness. This is seen in the appointment of Nkosazana Dlamini Zuma as one of the ministers in his cabinet. This came as a surprise to many as she was the forerunner for the presidency of the ANC. Although he is an affluent president, he seldom boasts about his assets and material wealth he has achieved over the years. Ramaphosa is very calm and well composed; even when the situation is very tense, he retains acts of quietness and calmness. Ramaphosa has the ability to put his own accomplishments and talents into proper perspective. He is willing to stand back, putting the interests of others first and facilitating their performance.

\section{Criticism on Ramaphosa's leadership}

Indeed, the leadership styles of Ramaphosa as outlined in the preceding section paint a good picture of the president. However, there have been voices criticising his leadership mainly on two issues. Firstly, the Marikana massacre ${ }^{1}$ that took place on 16 August 2012 involving the killing of 34 Lonmin strikers by the South African Police Service. According to Hart (2014:85), the president had 9\% share in Lonmin at the time of the massacre. Ramaphosa is criticised for the emails he wrote in response to the Lonmin strike where he said in Hart (2014) that:

$[T]$ he terrible events that have unfolded cannot be described as a labour dispute. They are plainly dastardly criminal and must be characterized as such. There needs to be concomitant action to address this situation. (p. 85)

Although the president apologised 5 years later for such comments, many viewed his apology as 'disingenuous and dishonest’ (Alexander 2017:1; cf. Boesak 2019:11). Boesak (2019) is of the opinion that the president as a:

$[W]$ ealthy shareholder and director of Lonmin, and as powerful member of the South African government and the ruling ANC, chose for the interest of wealth, power and privilege, and against the interests of the poor, the working class and the powerless. (p. 111)

Therefore, for Boesak (2019:11), the apology is not enough and it should be accompanied with the process of healing which the president himself could lead.

1.The Marikana massacre took place in Marikana, Rustenburg, North West province, South Africa. The massacre involved the killing of 34 miners by the South African South Africa. The massacre involved the killing of 34 miners by the South African
Police Service (SAPS) on 16 August 2012. The 34 miners were part of the strikers at the Marikana mine owned by Lonmin. 
The second issue is the Bosasa ${ }^{2}$ debacle. This, according to Styan and Vecchiatto (2019), involved 'Ramaphosa's son and a donation to his campaign fund for the ANC leadership a year earlier'. According to Basson (2019; cf. Motaung 2020:116), 'In November 2018, Ramaphosa admitted he'd received a R500 000.00 donation from Watson to his 2017 campaign fund for the ANC presidency'. Since this admission, there was growing concerns that even threatened the president's vision of new dawn (Styan \& Vecchiatto 2019). This was exacerbated by the public protector Busisiwe Mkhwebane's findings that the president had violated his oath of office by not declaring the donation made to him during his presidential campaign. Since then, there have been calls for Ramaphosa to declare all other donations that he had received during his presidential campaign, with some viewing the failure for disclosure as an impediment to the new dawn of vision of Ramaphosa.

\section{Ramaphosa and the use of 'Thuma Mina'}

In his State of the Nation Address (SONA) on 16 February 2018, President Ramaphosa quoted the Thuma Mina song by Hugh Masekela as follows:

\author{
I wanna be there when the people start to turn it around \\ When they triump over poverty \\ I wanna be there when the people win the battle against AIDS \\ I wanna lend a hand \\ I wanna be there for the alcoholic \\ I wanna be there for the victims of violence and abuse \\ I wanna lend a hand \\ Send me (Thuma Mina) (p. 1)
}

In this song, social issues that were destroying the very hope of South Africans are raised with the hope that one day things will turn around for better. In addition, when President Cyril Ramaphosa quoted this song, he was fully aware that South Africa is being destroyed by poverty, HIV and Aids, drug addiction, gender-based violence, xenophobia, corruption, racism and so on. Maluleke (2018) captures the intention of the president in using these words of 'Thuma Mina' as follows:

$[W]$ hen President Cyril Ramaphosa quoted - in his inaugural address to South Africa's Parliament - the song Send Me by Hugh Masekela, he was not only honouring the musician, but evoking the lyrics of an immensely popular traditional church chorus which highlights themes of self-sacrifice, individual responsibility and the importance of personal change in mindsets. (p. 1)

Just like Hugh Masekela and members of churches who used the song Thuma Mina in different languages and versions, President Ramaphosa sought to inspire South Africans to rise and volunteer their services in bringing about the desired transformation. Solutions to our country do not lie with government, but to the resourcefulness of every citizen when they realise their potential and participate in the rebuilding

2.Bosasa, a company founded in South Africa to offer different services to the government, was involved in allegations of corruptions involving politicians as heard
in the Zondo Commossion of Inquiry and subsequent testimonies of Angelo Aggrizzi. of a collapsing dream of a better life for all. Maluleke, as quoted above, is also of the view that the use of this song has deep religious roots that have carried the nation in difficult times, and these roots can be traced to Isaiah 6:8. By tapping into this resourcefulness and as a person with rich religious background and rich political heritage that encouraged the spirit of volunteerism, Cyril Ramaphosa was not just volunteering his services for a noble task of serving South Africa, he was also making efforts to inspire South Africans to do the same; hence the response received from the nation with the 'Thuma Mina' message was overwhelming (Maluleke 2018).

\section{Thuma Mina as a theological concept: Isaiah 6:8 Socio-historical context of Isaiah 6:8}

Isaiah is one of the widely read Old Testament books, but one that is very complex (Groenewald 2012:1) and has attracted controversies amongst scholars in diverse area, namely, firstly, there are different schools of thoughts around the authorship of the book. There is consensus amongst scholars that the book is named after prophet Isaiah (Young 1989:202); however, in terms of authorship, there is contestation. Some scholars insist that Isaiah son of Amoz has written the book (Berges 2010:553), whilst others talk about two or three authors with the inclusion of 'deutero-Isaiah' (Beuken 1992:78) and 'trito-Isaiah', respectively (Hill \& Walton 1991:319). Secondly, there are questions that raised the (dis)unity of the book. In line with the question on authorship, there are scholars who see the book as a unit (Baloyi 2007:106, 123), whilst others opted to divide the book into two, Isaiah 1-39 and Isaiah 40-66 (Kaiser 1991:204), and others into three, Isaiah 1-39, Isaiah 40-55 and Isaiah 56-66 (Baltzer 2010:262). Thirdly, the language and the interpretation of its message remains another area of contention; hence, Groenewald (2012:60 would have concluded that '.. it is problematic to reconstruct the processes of its formation and transmission'. Having noted the foregoing complexities around the book of Isaiah, it should be noted that it is not the intention of this article to investigate and find solutions to all these complex matters. What is of great significance for the purpose of this article is the political context within which the book is located and the prophetic message that accompanied the prophetic narrative of 'Thuma mina'. The book is written within the context of the empire and it covers the following political contexts: 'the Assyrian period (ca. 911-605 B.C.E.), the Neo-Babylonian period (ca. 625-539 B.C.E.), and the Persian period (ca. 550-333 B.C.E.)' (Baltzer 2010:261). This article, therefore, follows the same line of political interest as that of Lind (1997).

The book of Isaiah and his vision around 'Thuma Mina' is said to have taken place during the year when King Uzziah died and both pre-exilic, exilic and post-exilic are covered in this prophetic call narrative. Lind (1997:318) noted amongst others that the mentioning of King Uzziah mainly designates 
the time of the vision, however, '... it also marks the vision as dealing with public policy, the policy with which kings are occupied'; hence in his prophetic utterances, the words 'justice' and 'righteousness' were central in the Prophet's message. The prophetic narrative of Isaiah 6:8 is located in the first part of Isaiah (Is 1-39) and its focus is on exposing the sins, rebellion and disobedience of God's people and their pending judgement. The prophet spoke about the impending attack by Assyrians. It is in Isaiah 6:9-10 where the rebellion of Isaiah's audience is exposed - hardness of heart, failure to see the truth and their disobedience. When Isaiah enquired about longevity of this rebellion (Is 6:11), God opened his eyes to see the impending Babylonian captivity which lasted 70 years (Is 6:11-13). However, the second and or third part(s) of Isaiah's prophecy (Is 40-66) provided God's people with the much-needed hope of the coming salvation from Yahweh. The core of this message is also captured in Isaiah 6:13 with the promise of Israel's stump which remains a living hope for the exiles.

\section{Thuma Mina as a prophetic calling from God}

This article is founded and built on the presupposition that the Book of Isaiah, and in particular Isaiah 6, is the prophetic call narrative (Kaplan 1926:251; Lind 1997:317). Therefore, 'Here am I! Send me' (thuma mina) can be correctly ascribed as words used by prophet Isaiah in response to his prophetic calling. Isaiah responded to the conversation by God, 'Whom should I send as a messenger to this people? Who will go for us'? (Is 6:8b), by saying, 'Here am I! Send me' (Is 6:8c). There are four issues that are noteworthy that underpins our interpretation of Isaiah's response, 'here I am, send me' (thuma mina).

\section{'Thuma Mina' as a response of the prophet's experience of God}

The inspiration for Isaiah to volunteer in the spirit of 'Thuma Mina' came as a result of his encounter with God. In the vision that Isaiah saw as recorded in Isaiah $6: 1-4$, the prophet is not only allowed to be in the presence of God but also listen to the conversation by God. It is within the context of Isaiah overhearing the Yahweh's address, in the same light as Genesis 1:26, 'Who will go for us?', that Cross (1953:274) opines that Isaiah responded: 'Send me' (thuma mina). There are three distinct characters of God that inspired Isaiah to respond in this fashion, namely, firstly, 'the contrast between the earthly king Uzziah who dies' (6:1) and 'the King, YHWH [Yaweh] of hosts' (6:5), whose majesty defies decay. Beuken (2004:75) is critical regarding the authority that God's calling and commissioning to the prophet carries. Secondly, Isaiah's experience of the sending God is one who is seated at his throne of majesty, one filling the temple with his presence and thereby granted its significance in his calling and mission. Thirdly, God is defined by holiness and the need to be worshipped and served in holiness (Is 6:3). God's holiness is revealed as a measuring standard expected of God's people, which becomes a measure to judge their lifestyle under his rulership. God is said to be holy to define his perfection and dependability, and based on this clarity of vision, Isaiah was able to respond: 'Thuma mina'.

\section{Thuma Mina as a response by a human being}

What is interesting in Isaiah's response, 'send me' (thuma mina), is that the prophet was fully aware of his inability to match God's standards. He had to rely on the reliability on God's grace to succeed. Isaiah talks about his personal impurity and that of his audience (Is 6:5). The difference between Isaiah and his contemporaries is that he received the necessary cleansing from God to qualify as a person who was ready to volunteer his services as a messenger between God and his impure people. When Isaiah's lips were cleansed by a burning coal, the prophet was allowed to access the presence of God, to listen to God speaking and to be able to volunteer as a prophet. There are two critical issues that must be emphasised in this instance, namely, firstly, when Isaiah volunteered to serve as a prophet, it was an act of submission - willingness to serve in response to God's holiness, cleansing and commission (Woodbridge 2010:50). Secondly, the purification act constituted Isaiah's inauguration as a prophet (Kaplan 1926:251), an act which was conducted by God as an affirmation of his commissioning and the very approval of righteousness that a sinful person like Isaiah is able to receive out of grace. Beuken (2004:77) asserts: '[t]hat coal, which the seraph could only take up with tongs, did not scorch the prophet's lips but enabled him to express his readiness to serve YHWH [Yaweh] (6:7-8)'.

\section{Thuma Mina as a response by a prophet to work amongst human beings}

Prophet Isaiah was very aware that the context of his ministry was not a simple one. Isaiah was sent to people who are not capable of meeting God's moral and ethical standards according to God law. As much as the prophet will go and address his audience, Isaiah 6:9-10 reveals certain character traits about these people, namely, hardening of hearts, deaf ears, blind eyes and inability to turn to God for healing. It was going to be very difficult for Isaiah because his proclamation was going to be a fruitless exercise (McLaughlin 1994:5). Even after the prophet would have enquired from God, 'How long, O Lord?' (Is 6:11a), McLaughlin (1994:6) opines that, 'the subsequent description of devastation in vv. $11 b-12$ shows that this hardening is meant to last until the divine judgement has been fully implemented'. What is more interesting is that the hardening is seen as part of God's intervention in providing correction that would only become effective after they had received punishment for their wrong doing. It is remarked that the people themselves are not completely innocent prior to the hardening, and the hardening is implemented not to evoke divine punishment but to ensure that it not be avoided' (McLaughlin 1994:6).

\section{Thuma Mina as a response to carry a message of judgement and hope}

The message that the prophet had to God's people was threefold. Firstly, it was a confrontational message that speaks to their sins and the consequences thereof. The prophet had to remind them not only of their rebellion and unrepentant hearts, but also of the pending judgement 
where they will be taken to captivity. Secondly, it was a message to call God's people back to God's holiness code. According to Grey (2018:592), 'The prophet is sent as an embodied sign, or model of mimetic replication. He will be a voice calling his community to similarly mirror the holiness of Yahweh'. God's people were expected to be holy and meet God's moral and ethical standards, and the prophet was called to communicate this message to them. Thirdly, the prophet was to proclaim hope in the midst of hopelessness. Beuken (2004) asserts:

$[I] \mathrm{t}$ is only after the long learning process of a devastation to the second power (6:11-13a) that 'a holy seed' can make up for the earlier people's failing consent with the proclamation of YHWH's [Yaweh's] holiness (6:13b). (p. 78)

Van der Kooij (2014:24) adds: 'After being reduced to something like a bare tree, there will be new life going forth from Jerusalem in order to repopulate and rebuild Judah' (Van der Kooij 2014:24). It is this Messianic hope, one which the prophet defines in Isaiah 7:10-24, that inspired the prophet to respond with an emphatic, 'Thuma Mina' (Is 6:8).

\section{A prospect of Ramaphosa presidency through the lenses of Isaiah 6:8}

In the efforts to draw some parallels and lessons from Isaiah 6:8 and a prospect of Ramaphosa's presidency, we should acknowledge that there is a social, historical and political distance between the two. There are, however, for the purpose of this article, three distinctive connectors, namely, firstly, the 'Thuma mina' (Send me) concept and the underpinning spirit of voluntarism that accompanies it. Secondly, the political context of the empire, state of corruption and the need towards restoration. And thirdly, the appeal to the resourcefulness of God and that of human beings who, voluntarily respond to the need to stamp out corruption.

In the light of the foregoing, this article will proceed to unmask existing parallels that can be drawn from the 'Thuma Mina' in Isaiah 6:8 and the 'Thuma Mina' of Ramaphosa. Firstly, the president has always been conscious of the historical roots of 'Thuma Mina' that they go beyond Hugh Masekela's Thuma Mina and the chorus that he grew up singing - be it in the church or in the liberation struggle. It connects with Isaiah 6 and the story of prophet Isaiah (Maluleke 2018). Secondly, inspired by a sense of calling, just like the prophet Isaiah, Cyril Ramaphosa raised his hand to lead the ANC and the nation towards healing after a decade of decay under the leadership of Jacob Zuma. Just as in the case of Hugh Masekela, Ramaphosa saw South Africans as his resource and thereby took the opportunity to inspire them to volunteer their services through 'Thuma Mina'. Thirdly, just like the prophet Isaiah, Ramaphosa never looked at himself as a saint but a servant of the people who, like prophet Isaiah, remains forever indebted to God something that we always pick at the end of his address to the nation: 'May God bless South Africa and her people'. Fourthly, just like prophet Isaiah, Ramaphosa is called to confront social ills and decay of our society. He is expected to confront the powers that be and also deal with the stubbornness of the hearts of many who continue in the same track of corruption, racism, gender-based violence and so on. What is needed is boldness in dealing with issues of corruption and all other social ills in South Africa. Fifthly, for Ramaphosa to succeed in his presidency - in order for him to set the country on the recovery paths in all areas - he should take advantage of the generosity of South Africans and their 'ubuntu' as they volunteer to support his vision for this nation. Sixthly, but not the least, the president should never cease to remain connected to God for him to succeed. Talking about the sovereignty of God and speaking in the context guaranteed success in Isaiah's calling, Beuken (2004) concluded:

Whereas the people of the earthly king are destined to ruin (6:11-12), the heavenly king, who governs the world by his holiness (6:3), has the ability to ensure the emergence of a holy seed that will live in harmony with him (6:13). (p. 75)

Coupled with the hallmarks of Ramaphosa's leadership style of being a negotiator, unifier, ethical, transformation and a humble person, which defines his servant leadership skills (see Kgatle 2018:4-6), he stands a good prospect of succeeding against all odds in his tenure as a president.

\section{Conclusion}

Whilst South Africa has a long history of failed projects, the Ramaphosa presidency and its appeal for active citizenry, through the inspiration of 'Thuma Mina', have the prospect of succeeding in many respects. The 'Thuma Mina' ethos is more than a song and a biblical phrase; it is viable and practical even for a South African style of governance. Therefore, it will continue to define the Ramaphosa presidency and his leadership style going to the future. Coupled with his leadership style, the spirit of volunteerism and ability to listen as a servant leader, Ramaphosa's 'Thuma Mina' will remain a driver of a new dawn and its success. However, for the above to happen, we suggest that the 'Thuma Mina' project should be a message that emanates directly from God. Therefore, its full potential shall be realised when a nation and its people have an encounter with their creator. The response to 'Thuma Mina' as a calling does not only carry the message of hope to the people but also confrontation of sins in a broken world.

\section{Acknowledgements}

The authors would like to thank the Department of Christian Spirituality, Church History and Missiology for the support provided in conducting this research.

\section{Competing interests}

The authors declare that they have no financial or personal relationships that may have inappropriately influenced them in writing this article. 


\section{Authors' contributions}

T.D.M. contributed on the 'Thuma Mina' as a theological concept in Isaiah 6:8 and M.S.K. on Ramaphosa, his leadership style and use of the 'Thuma Mina' concept.

\section{Ethical considerations}

The ethical clearance was issued by the University of South Africa, College of Human Sciences Research Ethics Review Committee - 2019-CHS-90343018-Dept.

\section{Funding information}

This study was financially supported by the University of South Africa.

\section{Data availability}

Data sharing is not applicable to this article as no new data were created or analysed in this study.

\section{Disclaimer}

The views and opinions expressed in this article are those of the authors and do not necessarily reflect the official policy or position of any affiliated agency of the authors.

\section{References}

Alexander, P., 2017, Cyril Ramaphosa's Marikana massacre "apology" is disingenuous and dishonest, viewed 11 May 2017, from https://theconversation.com/cyrilramaphosas-marikana-massacre-apology-is-disingenuous-and-dishonest-77485.

Baloyi, M.E., 2007, 'Unity of the Book Isaiah: Neglected evidence (Re-) considered', OTE 20(1), 105-127, viewed 21 June 2019, from https://0-hdl-handle-net.oasis. unisa.ac.za/10520/EJC85857.

Baltzer, K., 2010, 'The book of Isaiah', The Harvard Theological Review 103(3), 261-270, viewed 01 July 2010, from https://www.jstor.org/stable/40731070.

Barnard-Naudé, J., 2020, 'We must be able to get used to the real', Philosophy \& Rhetoric 53(3), 217-224, viewed 29 July 2020, from https://www.jstor.org/ stable/10.5325/philrhet.53.3.0217.

Basson, A., 2019, Blessed by Bosasa: Inside Gavin Watson's state capture cult Jonathan Ball, Johannesburg.

Beckmann, J., 2019, 'Thuma mina and education: Volunteerism, possibilities and challenges', South African Journal of Education 39(1), 1-8. https://doi. org/10.15700/saje.v39ns1a1819

Berges, U., 2010, 'The book of Isaiah as Isaiah's book', OTE 23(3), 549-573, viewed 21 November 2020, from https://0-hdl-handle-net.oasis.unisa.ac.za/10520/ AJA10109919_439.

Beuken, W.A., 1992, 'Isaiah 34: Lament in Isaianic context', Old Testament Essays 5(1), 78-102.

Beuken, W.A., 2004, 'The manifestation of Yahweh and the commission of Isaiah: Isaiah 6 Read against the background of Isaiah 1', CTJ 39(1), 72-87.

Boesak, A.A., 2019, Children of the Waters of Meribah: Black Liberation Theology, the Miriamic Tradition, and the Challenges of Twenty-First-Century Empire, Wipf and Stock Publishers, Eugene, OR.

Burnard, M., 2017, Cyril Ramaphosa, seven facts South Africans need to know, viewed 21 December 2017, from https://gatewaynews.co.za/cyril-ramaphosa-sevenfacts-south-africans-need-to-know/.

Butler, A., 2011, Cyril Ramaphosa, Jacana Media, Johannesburg.

Cilliers, J., 2017, 'South Africa's Prospects under Cyril Ramaphosa', Institute for Security Studies 1-19, viewed 12 January 2018, from https://issafrica.org/ research/books-and-other-publications/south-africas-prospects-under-cyrilramaphosa.
City Press, 2017, Do not hold your breath. Ramaphosa will not rescue the ANC, viewed 08 December 2017, from https://www.news24.com/citypress/voices/dont-holdyour-breath-ramaphosa-will-not-rescue-the-anc-20171207.

Cross, F.M., 1953, 'The Council of Yahweh in Second Isaiah', Journal of Near Eastern Studies 12(1), 274-277, viewed 20 June 2020, from http://www.jstor.com/ stable/542950.

DPME, 2018, President Cyril Ramaphosa: Profile, viewed 14 March 2018, from https:// www.dpme.gov.za/about/Pages/President-Cyril-Ramaphosa.aspx.

Grey, J.N., 2018, 'Isaiah's vision of Yahweh and ethical replication', Old Testament Essays 31(3), 591-612. https:/doi.org/10.17159/23123621/2018/v31n3a11

Groenewald, A., 2012, 'Isaiah 1:2-3 and Isaiah 6: Isaiah "a prophet like Moses" (Dt 18:18)', HTS Teologiese Studies/Theological Studies 68(1), Art. \#1311, 1-7. https:// doi.org/10.4102/hts.v68i1.1311

Göranzon, A., 2019, 'Thuma mina! Who sends whom? How South Africa as a Rainbow Nation has been perceived in the Church of Sweden', Alternation 26(1), 174-193. https://doi.org/10.29086/2519-5476/2019/v26n1a8

Hart, G.P., 2014, Rethinking the South African crisis: Nationalism, populism, hegemony, vol. 20, University of Georgia Press, Athens, GA.

Hartley, R., 2017, Ramaphosa: The man who would be king, Jonathan Ball, Johannesburg.

Johannesburg Review of Books, 2018, Is Cyril Ramaphosa the man to lead South Africa out of its political and economic crisis?, viewed 05 March 2018, from https:// johannesburgreviewofbooks.com/2018/03/05/is-cyril-ramaphosa-the-man-tolead-south-africa-out-of-its-political-and-economic-crisis-read-an-excerpt-fromramaphosa-the-man-who-would-be-king-by-ray-hartley/.

Hill, A.E. \& Walton, J.H., 1991, A survey of the Old Testament, Zondervan, Grand Rapids, MI.

Kaiser Jr., W.C., 1991, Toward an Old Testament Theology, Zondervan, Grand Rapids, MI.

Kaplan, M.M., 1926, 'Isaiah 6:1-11', Journal of Biblical Literature 45(3-4), 251-259, viewed 21 July 2020, from http://www.jstor.com/stable/3260080.

Kgatle, M.S., 2016, Servant leadership: The path to success, Lulu Press, Inc Morrisville, NC.

Kgatle, M.S., 2018, 'Servant leadership: An urgent style for the current political leadership in South Africa', Verbum et Ecclesia 39(1), a1815. https://doi. org/10.4102/ve.v39i1.1815

Lind, M.C., 1997, 'C.A. Political implications of Isaiah 6', Broyles, C.C. and Evans (eds.), Writing and Reading the scroll of Isaiah 1(1), 317-338. https://doi. org/10.1163/9789004275942_018

Mail \& Guardian, 2019, Editorial: The destruction of Thuma Mina, viewed 22 March 2019, from https://mg.co.za/article/2019-03-22-00-editorial-the-destruction-ofthuma-mina/.

Maluleke, T., 2018, 'Op-Ed: The deep roots of Ramaphosa's 'Thuma Mina', Daily Maverick, 22 February 2018, viewed 06 July 2020, from Dailymaverick.co.za/ article/2018-02-22-op-ed-the-deep-roots-of-ramaphosas-thuma-mina/\#gsc.tab=0.

McLaughlin, J.L., 1994, 'Their hearts were hardened: The use of Isaiah 6, 9-10 in the Book of Isaiah', Biblica 75(1), 1-25, viewed 10 August 2020, from http://www. jstor.com/stable/42611360

Motaung, S.P., 2020, The Day the South African Constitutional Court Legalised Crime and Corruption- To the Benefit of the Guptas, Dorrance, Pittsburg.

News24, 2017, Is Ramaphosa the ethnic unifier the ANC needs?, viewed 08 December 2017, from https://www.news24.com/news24/columnists/mpumelelo_mkhabela/ is-ramaphosa-the-ethnic-unifier-the-anc-needs-20171208.

Nkambule, S.P., 2014, The pursuit of wealth, Palgrave Macmillan, London.

Odwa, M.J.O., 2018, 'Cyril Ramaphosa's 2018 Thuma Mina moments', Times Live, 20 December 2018, viewed 06 July 2020, from Timeslive.co.za/news/southafrica/2018-12-20-cyril-ramaphosas-018-thuma-mina-moments/.

Ramaphosa, 2017, Ramaphosa, unifier and builder, our future president, viewed 14 March 2018, from http://www.presidency.gov.za/profiles/president-cyril-ramaphosa.

SONA, 2018, South African state of the nation address, viewed 16 February 2018, from https://www.gov.za/speeches/state-nation-address-2018.

South African History Online, 2018, Cyril Ramaphosa, viewed 02 March 2018, from https://www.sahistory.org.za/people/cyril-matamela-ramaphosa.

Styan, J.B. \& Vecchiatto, P., 2019, Bosasa Billions: How the ANC sold its soul, LAPA Uitgewers, Pretoria

Van der Kooij, A., 2014, 'Stump or stalk: Isaiah 6:13 in the light of the Ancient versions', Journal of Northwest Semitic Languages 40(2), 17-26, viewed 01 January 2014, from https://0-hdl-handle-net.oasis.unisa.ac.za/10520/EJC167157.

Woodbridge, N.B., 2010, 'Living theologically - Towards a theology of Christian practice in terms of the theological triad of orthodoxy, orthopraxy and orthopraxy as portrayed in Isaiah 6:1-8: A narrative approach', HTS Teologiese Studies/ Theological Studies 66(2), Art. \#807, 1-6. https;//doi.org/10.4102/hts.v66i2.807

Young, E.D., 1989, An introduction of the Old Testament, Eerdmans, Grand Rapids, MI. 